Information for citation:

Ibragimova S. V. Regulyativnaya funktsiya grazhdanskogo prava [The Regulatory Function of Civil Law]. Vestnik Permskogo Universiteta. Juridicheskie Nauki - Perm University Herald. Juridical Sciences. 2016. Issue 34. Pp. 413-417. (In Russ.). DOI: 10.17072/1995-4190-2016-34-413-417.

UDC 347.1

DOI: 10.17072/1995-4190-2016-34-413-417

\title{
THE REGULATORY FUNCTION OF CIVIL LAW
}

\author{
S. V. Ibragimova \\ Perm State University \\ 15, Bukireva st., Perm, 614990, Russia \\ ORCID: 0000-0001-6426-2649 \\ ResearcherID: Q-4386-2016 \\ e-mail: sv.ibragimova@gmail.com
}

Introduction: the article is devoted to research into the regulatory function of civil law. Functions of the law, its subject, method and principles form the basis for studying the branch of law and its key features. Civil law performs both regulatory and protective functions. The regulatory function plays a major role in the impact of civil law on social relations. Purpose: to give an insight into the regulatory function of civil law on the basis of the analysis of scientific papers and reports. Methods: empirical methods of comparison, description, and interpretation, theoretical methods of formal logic and dialectics have been used. Results: the regulatory function of civil law is aimed at meeting objectives of civil law as a branch of law by means of establishing unambiguous property and personal non-property relations based on equality, autonomy of will and property independence of parties, as well as by means of ensuring a good balance of private interests existing in society and also by providing conditions for active engagement of entities in the production and consumption of material benefits, etc. Conclusions: the regulatory function of civil law is determined by regulations which protect the existing positive property and non-property social relations based on equality, autonomy of will and property independence of parties, and provide conditions for the development and spread of these relations. The law does not protect negative relations that exist in the private sector. Civil-law mechanisms are provided to ensure that negative relations are restricted and eliminated. The impact of civil law should be provided timely and contribute to the establishment of new positive relations resulting from achievements in science and technology and social development.

Keywords: regulatory function of civil law; property and non-property relations; private interests

\section{Information on Russian}

\section{РЕГУЛЯТИВНАЯ ФУНКЦИЯ ГРАЖДАНСКОГО ПРАВА}

\section{С. В. Ибрагимова}

Кандидат юридических наук, доцент кафедры гражданского права Пермский государственный национальный исследовательский университет 614990, Россия, г. Пермь, ул. Букирева, 15

ORCID: 0000-0001-6426-2649

ResearcherID: Q-4386-2016

e-mail: sv.ibragimova@gmail.com

(C) Ibragimova S. V., 2016 
Введение: статья посвящена исследованию регулятивной функции гражданского права. Функиии права наряду с его предметом, методом и принципами образуют базис для исследования отрасли права и ее сущностных характеристик. Гражданское право осуществляет как регулятивную, так и охранительную функции, причем регулятивная функиия является преимущественным направлением воздействия гражданского права на общественные отношения. Цель: сформировать представление о регулятивной функиии гражданского права на основе анализа научных источников. Методы: эмпирические методы сравнения, описания, интерпретации; теоретические методы формальной и диалектической логики. Результаты: регулятивная функция гражданского права предопределена достижением задач, стоящих перед гражданским правом как отраслью права, по установлению определенности в имущественных и личных неимущественных отношениях, основанных на равенстве, автономии воли и имущественной самостоятельности участников; обеспечению баланса частных интересов, существующих в обществе; созданию условий для активного участия субъектов в производстве и потреблении материальных благ и др. Выводы: регулятивная функиия гражданского права определяется наличием норм, которые закрепляют существующие в обществе положительные имущественные и неимущественные отношения, основанные на равенстве, автономии воли и имущественной самостоятельности участников, и создают условия для их развития и распространения. Негативные фактически существующие в частной сфере отношения правом не поддерживаются, в связи с этим создаются гражданско-правовые механизмы для их ограничения и дальнейтего искоренения. Воздействие гражданского права должно быть своевременным при формировании в обществе новых положительных отношений, обусловленных достижениями науки и техники, развитием самого общества.

Ключевые слова: регулятивная функция гражданского права; имущественные и неимущественные отношения; частные интересы

\section{Introduction}

Functions of law, along with its subject, method and principles, form the basis for studying a branch of law and its essential characteristics. As was rightly noted by S. Alekseev, the active role of law in society manifests itself in its functions, that is, the directions of legal efforts expressing the role of law in arranging (streamlining) social relations [1].

Like any branch of law, civil law performs both regulatory and protective functions, the former playing the major role in the impact of civil law on social relations. Providing a wide range of regulatory impact, civil law determines the legal status of participants of civil transactions, the grounds for some certain rights to arise and the procedure for the exercise of these rights (in particular, property right and other proprietary rights, rights to the results of intellectual activity and means of individualization equated with these), regulates the relationships connected with participation in corporate organizations or with their management, contractual and other obligations, other property and personal non-property relationships based on equality, autonomy of will and property independence of the participants. The protective function of civil law is expressed in the determination of civil rights and interests which are taken under its protection, the establishment of mechanisms in the form of prohibitions, measures of civil law enforcement aimed at restoration of violated civil rights and interests, along with awards of compensation.

\section{Main Part}

Based on the general theoretical understanding of the functions of law, the regulatory function of civil law should be considered on the basis of the social purpose of civil law as the central branch of private law. As is noted by A. Komarov, the concept of "private law" lies in the fact that in the process of evolution the state acknowledges the need to abandon the strict regulation of relations between individuals through mandatory regulations and allow them, within certain limits, to freely regulate their relationships themselves; in practice this 
means the creation by individuals of their own law, because the law protects private arrangements, establishing penalties for their violation the same as for violation of the rules of law [3].

Civil law regulates property and non-property relationships of individuals based on their interests, mutual benefit, autonomy of will, and equality. It aims to provide their participants with freedom, opportunities to take the initiative and to encourage entrepreneurial qualities. Civil law relationships are socially useful and necessary for society. A significant number of these relationships are property relations, which belong to the economic sphere of society, providing economic results, development of the society and material well-being of its members.

As is noted by E. Durkheim, social progress is improvement of social relations in such a way that forces individuals to produce the result, for achievement of which they have been established, to the fullest extent [2]. However, in the private sphere it is only possible to force individuals to produce the result in an indirect way, by creating the conditions for their entry into social relationships.

Undoubtedly, the achievements in science and technology, the complication of the systems' functioning, the narrowing of specialized functions carried out by individuals predetermined the dependence of society members on each other and the need for social relations between them. However, stressing the importance of these factors' impact on social relationships, we should not underestimate the role of law in their arrangement.

First of all, law is the guarantor of balancing different interests existing in the society. Private interests of subjects have different direction vectors which often contradict each other. On the one hand, there are entrepreneurs who are the main movers of the society and are interested in maximizing the economic result (in gaining profit) through economic activities; on the other hand, there are citizens acting as consumers and participants of labor (contract) relationships, interested in obtaining material values while spending minimum amount of money and in receiving substantial payments for their work, which would enable them to ensure a decent standard of living, etc.

Providing conditions for the realization of all the existing private interests in the desired form seems unattainable. The object of the state is to find a compromise between the different interests and to ensure the reasonable satisfaction of the interests of all participants in social relationships through the formation of mandatory rules.

For civil law relations, the same as for any other legal relations, the certainty and stability of legal regulation are of great importance. The existence of rules of law that indicate which behavior options can be chosen by subjects and which rights and obligations they obtain in each case provide the uniform understanding of legal relations and consequences that they entail.

When considering the issue of legal effects on social relations, it should also be taken into account that their participants may not have the whole spectrum of knowledge existing in the society; so, as was rightly noted by F. Schauer, rules of law indicate the proper course of action for subjects (e. g., a maximum speed limit sign notifies the road users of the safe speed on this segment of the road) [4].

In civil law, legal regulation is based on the principle that "everything is permitted that is not expressly prohibited by law". The legitimacy of civil relations is assumed, and in most cases it is not subject to public assessment, until the participants of legal relations or other persons will not report in the prescribed form of the infringement of rights (public assessment is carried out regardless of the desire of subjects in the cases prescribed by law: state registration of rights to immovable property, mandatory notarization of transactions, etc.).

According to American scientists T. Wilkinson-Ryan and D. Hoffman, in the private sphere, moral norms and ethical principles affect the formation of relationships between people to a greater extent than legal rules. Knowledge of a legal norm has a limited impact on the behavior of citizens, for whom there are issues of greater importance: their personal commitments, their fear to disappoint somebody, not to fulfill a promise, incur disapproval from others, or, on the contrary, to seem generous; thus, when entering into and implementing legal relations, persons are governed by social and ethical aspects, often not taking advantage of the rights guaranteed to them by law and in some cases not using the prescribed sanctions [6].

The above judgments are fully applicable to the Russian reality. For Russian citizens, social and 
moral aspects are also of great importance when entering into civil law relations. For example, personal sympathy or antipathy, along with public opinion, can be the dominant factors when making a decision to conclude a contract, select a contractor, determine rights and obligations, use or fail to use remedies.

The private law sphere is often regarded by citizens as their personal sphere of life, which cannot be interfered by other persons, including the state, without their consent. In the business field, nonlegal factors may also be of value in the course of entering into and implementing civil law relations (e. g., the criterion of personality is often applied when choosing a contractor under the contract, resulting in choosing a member or sole executive body of the "tried-and-true" partner, with a "word of honor" being the extralegal way to ensure the performance of the obligation; formation of conditions of the agreement and the procedure for its conclusion can also depend on the criterion of personality, etc.).

Considering the nature of private relations, the legislator establishes measures of possible and appropriate behavior of subjects in civil law norms and defines the principles and legal imperatives of civil law. For example, the inadmissibility of legal invasion into certain areas of subjects' life is expressed by the establishment in the civil law of the principle of inadmissibility of arbitrary interference into private affairs. Legal imperatives of this principle can be seen in the prohibitions of arbitrary interference into the sphere of personal relations and into the legitimate activities of a legal entity; the inadmissibility of forcing the exercise of a subjective civil right, including its cessation.

The dependence of legal regulation on social relations is beyond doubt as the role of law consists in their harmonization. When developing rules of law, the legislator should not allow for a considerable gap to arise between the existing social relations and legal regulations. Non-compliance of law norms with the internal beliefs and principles of citizens and the lack of consideration of their opinion as "consumers" of law tends to undermine their faith in justice and prevents the formation and development of their positive legal sense and their adoption of a high level of legal conscience.
At the same time, when legal provisions meet expectations of the participants of legal relations, being clear, systemic and well-defined, norms of law become internal beliefs and, as a result, appear to be an integral part of lives of citizens. According to S. Silbey, established legal regulations make many legal institutions expected and understandable, becoming not only a mandatory, but also natural part of everyday public life (e. g., legal provisions on contracts, property or traffic rules) [5].

The purpose of civil law is to secure only the positive property and non-property relations based on equality, autonomy of will and property independence of the participants, providing conditions for their development and spread. The existing negative social legal relations are not supported by the law and, furthermore, law establishes mechanisms for their limitation, and when required elimination.

The impact of law on social relations should be provided dynamically, on a regular basis, in pursuit of their development and improvement. Upon the development of civil law regulation, achievements of science and technology that improve the quality of citizens' life should be taken into account.

For example, the invention of a personal computer and the Internet (the global system of integrated computer networks for storage and transmission of information), followed by the development of technologies in this area, has led to the appearance of new items of intellectual property (computer programs, databases); to changes in the settlement system; to the widespread usage of non-cash transactions and bank cards; to conclusion of various contracts through the Internet and the possibility of their execution in the virtual space; to changes in the processes related to the data search, storage, transmission, processing, usage, protection, etc. The development and adoption of a considerable number of new legal provisions concerning these technologies ensured certainty in social relations, their stability, and pointed to the admissibility of further development of technologies in this field. Legal protection was also required in order to establish prohibitions for commission of actions undesirable for society when using a personal computer and the Internet and to inform subjects about sanctions for these illegal acts. 


\section{Conclusions}

The regulatory function of civil law is determined by the presence of norms that enshrine the positive property and non-property relations based on equality, autonomy of will and property independence of the participants, and create conditions for their development and spread. Negative legal relationships that exist in the private sphere are not supported by law, so civil law mechanisms are established for their restriction and further elimination. The impact of civil law should be timely and relevant to the formation of new positive social relationships due to the achievements of science and technology and the development of society itself.

The regulatory function of civil law is predetermined by the achievement of the objectives faced by civil law as a branch of law in establishing certainty in property and personal non-property relations based on equality, autonomy of will and property independence of the participants; in ensuring a balance of private interests that exist in the society; in providing conditions for active participation of subjects in the production and consumption of material goods, etc.

The proper definition of the essence of social relations being regulated, the compliance of civil law regulation with the progressive development of society, its coherence and consistency determine the orderliness of civil law relations.

\section{References}

1. Alekseev S. S. Obshchaya teoriya prava: $v 2 t$. [General Theory of Law: in 2 vols.]. Moscow, 1981. Vol. 1. 361 p. (In Russ.).

2. Durkheim E. O razdelenii obshchestvennogo truda [The Division of Labor in Society]. Moscow, 1996. 432 p. (In Russ.).

3. Komarov A. S. Grazhdanskiy kodeks Rossii kak istochnik chastnogo prava; pod red. S. S. Alekseeva [The Civil Code of Russia as a source of private law; ed. by S. S. Alekseev]. Razvitie osnovnykh idey Grazhdanskogo kodeksa Rossii v sovremennom zakonodatel'stve $i$ sudebnoy praktike: sbornik statey, posvyashchennyj 70-letiyu S. A. Khokhlova - The development of basic ideas of the Russian Civil Code in modern legislation and judicial practice: collection of scientific articles dedicated to the $70^{\text {th }}$ anniversary of S. A. Khokhlov. Moscow, 2011. Access from the legal reference system ConsultantPlus. (In Russ.).

4. Schauer F. How (and if) law matters. Harvard Law Review. May 2016. № 7, vol. 129. Pp. 350-359. (In Eng.).

5. Silbey $S$. Everyday life and the constitution of legality; M. D. Jacobs \& N. Hanrahan (Eds.). The Blackwell companion to the sociology of culture. Malden, MA: Blackwell Publishing. 2005. Pp. 332-345. (In Eng.).

6. Wilkinson-Ryan T., Hoffman D. The common sense of contract formation. Stanford Law Review. June 2015. Issue 6, vol. 67. Pp. 12691301. (In Eng.).

\section{References in Russian}

1. Алексеев С. С. Общая теория права: в 2 т. М.: Юрид. лит., 1981. Т. 1. 361 с.

2. Дюркгейм Э. О разделении общественного труда. М.: Канон, 1996. 432 с.

3. Комаров А. С. Гражданский кодекс России как источник частного права // Развитие основных идей Гражданского кодекса России в современном законодательстве и судебной практике: сб. ст., посвященный 70-летию С. А. Хохлова / С. С. Алексеев, В. С. Белых, В. В. Витрянский и др.; под ред. С. С. Алексеева. М.: Статут, 2011. [Электронный ресурс]. Доступ из справ.-правовой системы «КонсультантПлюс».

4. Schauer F. How (and if) law matters // Harvard Law Review. May 2016. № 7, vol. 129. Pp. 350-359.

5. Silbey $S$. Everyday life and the constitution of legality // The Blackwell companion to the sociology of culture. M. D. Jacobs \& N. Hanrahan (Eds.) Maldem, MA: Blackwell publishing, 2005. Pp. 332-345.

7. Wilkinson-Ryan T., Hoffman D. The common sense of contract formation // Stanford Law Review. June 2015. Iss. 6 (vol. 67). Pp. 1269-1301. 